\title{
Commentary: Valve choice in dialysis-dependent patients: A question of patient durability
}

\author{
Marc Gillinov, MD, Stephanie Mick, MD, and Per Wierup, MD, PhD \\ From the Department of Thoracic and Cardiovascular Surgery, Cleveland Clinic, Cleveland, Ohio. \\ Disclosures: Dr Gillinov serves as a consultant to Medtronic, CryoLife, Edwards Lifesciences, Abbott, AtriCure, \\ and ClearFlow; he has rights to equity in ClearFlow. Dr Mick serves as a consultant to Medtronic and CryoLife. \\ Dr Wierup serves as a consultant to Medtronic and CryoLife. \\ Received for publication Oct 9, 2018; accepted for publication Oct 9, 2018; available ahead of print Nov 20, 2018. \\ Address for reprints: Marc Gillinov, MD, Department of Thoracic and Cardiovascular Surgery, Cleveland Clinic, \\ Desk J4-1, 9500 Euclid Ave, Cleveland, OH 44195 (E-mail: gillinom@ccf.org). \\ J Thorac Cardiovasc Surg 2019;158:814-5 \\ $0022-5223 / \$ 36.00$ \\ Copyright $\odot 2018$ by The American Association for Thoracic Surgery \\ https://doi.org/10.1016/j.jtcvs.2018.10.049
}

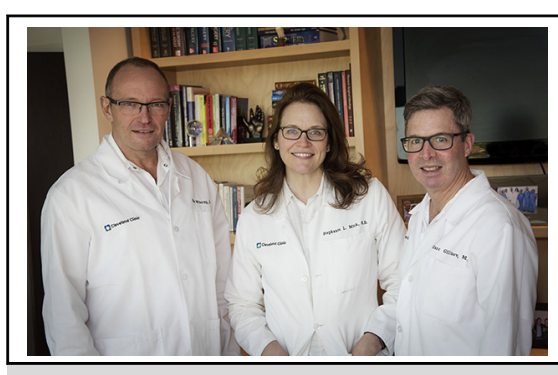

Per Wierup, MD, PhD, Stephanie Mick, MD, and Marc Gillinov, MD

\section{Central Message}

Biological prostheses are appropriate for nearly all dialysis-dependent patients who require heart valve replacement.

See Article page 805 . durability. Conversely, mechanical valves invariably require anticoagulation therapy but are not subject to structural valve deterioration. Patients often ask themselves whether they would prefer lifelong warfarin therapy or a late reoperation/reintervention. Generally unspoken, but still informing prosthesis choice, is an additional question: What is the life expectancy (ie, durability) of the patient? In their analysis of valve replacement in dialysis-dependent patients, Manghelli and colleagues ${ }^{1}$ find that the answer to this question guides prosthesis choice in this patient group.

Small studies have suggested that biological valves are prone to early calcification and degeneration when placed in patients with end stage renal disease (ESRD)., ${ }^{2,3}$ Recognition of this phenomenon led early guidelines to recommend mechanical valve replacement in such patients. ${ }^{4}$ Subsequent guidelines documents backed away from this stance, instead offering the bland (and unhelpful) suggestion that prosthesis choice should be "individualized." ${ }^{5}$ The data presented by Manghelli and colleagues, ${ }^{1}$ in contrast, provide a clear and compelling argument for biological valves as the default option in most dialysisdependent patients who require heart valve replacement.

Patients receiving dialysis have an average 5-year survival of $40 \% .{ }^{6}$ For dialysis-dependent patients who require heart valve replacement surgery, survival is even worse. Although the study was limited by incomplete follow-up (survival data were available for only $81 \%$ of patients), Manghelli and colleagues ${ }^{1}$ found that 5 -year survival was $23 \%$ after biological valve replacement and $33 \%$ after mechanical valve replacement; the median survivals in the 2 groups were approximately 2 and 3 years, respectively.
After adjusting for comorbid conditions, there was no difference in survival based on prosthesis choice. Survival was poor regardless of valve type, and no patient in the study survived more than 13 years. The article's central figure tells the story: 5-year survival is dismal in these patients.

Is there a cohort of dialysis-dependent patients who might live longer than 5 years? Manghelli and colleagues ${ }^{1}$ answer this question in the affirmative, but note that it is a very small group of patients. Only $7 \%$ of patients had an estimated 5-year survival $>5$ years; these were patients between ages of 30 and 40 years who had good functional status and who did not have diabetes. We must put this statement in context by remembering that 10 -year survival was quite rare. Therefore, even in younger dialysis-dependent patients, one can argue persuasively for placement of a biological valve.

Given the documented high procedural mortality and morbidity and limited intermediate survival in dialysisdependent patients undergoing heart valve replacement, investigation of transcatheter valve replacement options is warranted in this population. The authors have experience with this approach in patients with ESRD, but results of these procedures are not reported.

Manghelli and colleagues ${ }^{1}$ provide important guidance for management of ESRD. When considering valve replacement surgery in dialysis-dependent patients, choice of prosthesis must be dictated overwhelmingly by patient 
condition. Durability (ie, survival) is the primary consideration, and this should lead to choice of a bioprosthesis in nearly all patients.

\section{References}

1. Manghelli JL, Carter DI, Khiabani AJ, Gauthier JM, Moon MR, Munfakh NA, et al. A 20-year multicenter analysis of dialysis-dependent patients who had aortic or mitral valve replacement: implications for valve selection. J Thorac Cardiovasc Surg. 2019;158:805-13.e2.

2. Herzog CA, Ma JZ, Collins AJ. Long-term survival of dialysis patients in the United States with prosthetic heart valves: should ACC/AHA practice guidelines on valve selection be modified? Circulation. 2002;105:1336-41.
3. Gelsomino S, Morocutti G, Masullo G, Cheli G, Poldini F, Da Broi U, et al. Open heart surgery in patients with dialysis-dependent renal insufficiency. J Card Surg. 2001;15:400-7.

4. ACC/AHA guidelines for the management of patients with valvular heart disease. A report of the American College of Cardiology/American Heart Association. Task force on practice guidelines (committee on management of patients with valvular heart disease). J Am Coll Cardiol. 1998;32:1486-588.

5. Nishimura RA, Otto CM, Bonow RO, Carabello BA, Erwin JP III, Guyton RA, et al. 2014 AHA/ACC guidelines for the management of patients with valvular heart disease: a report of the American College of Cardiology/American Heart Association task force on practice guidelines. Circulation. 2014;129:e521-643.

6. US renal data system annual data report. 2018. Available at: http://www.usrds.org/ adr.htm. Accessed October 25, 2018. 